\title{
Contribution of Scientific Analyses to the Archaeological Assessment of Pottery Production in Turnov, Czech Republic
}

\author{
Kristýna Matějkováa ${ }^{a}$ Henryk Stoksik ${ }^{b}$ \\ anstitute of Archaeology, Faculty of Arts, Charles University, Celetná 20, 116 42, Prague, Czech Republic \\ ${ }^{b}$ Department of Ceramics and Glass, Academy of Fine Arts, Plac Polski 3-4, 50 156, Wroctaw, Poland
}

ARTICLE INFO:

\section{Article history:}

Received: 5 November 2011

Accepted: 20 December 2011

\section{Keywords:}

Pottery

scientific analysis

Turnov

firing temperatures

Middle Ages

Modern Period

\begin{abstract}
$A B S T R A C T$
The analysis of mediaeval and post-mediaeval pottery assemblages from the town of Turnov have confirmed the assumption that the current scope of research does not provide enough relevant data for a detailed understanding of the evolution of local pottery production. Macroscopic observations are in a certain sense limited and the application of scientific analyses has promised to broaden our knowledge. This paper aims to provide insight into the topic and to address related questions. We also assess the extent to which laboratory results (particularly of firing temperatures) may be affected by the chosen method of analysis.
\end{abstract}

\section{Introduction}

The town of Turnov is located in north east Bohemia on a promontory above the Jizera River. Because of the absence of historic written sources we can only roughly estimate its foundation to the mid- $13^{\text {th }}$ century. The site on which the town was founded did not belong to a prehistoric settlement area though numerous later settlement activities were documented by the $12^{\text {th }}$ century. ${ }^{1}$ The existence of small local settlements at the time (Maškovy zahrady, Nudvojovice, Hruštice) are considered determinants of the foundation of the old town (Klápště 2005, 123).

Despite its early emergence, and good connections with long-distance trade routes, Turnov never acquired any particular importance during its existence. It is a small vassal town that persisted until late modern times (Prostředník 2000, 14). Like most of its contemporaries Turnov suffered

\section{"Corresponding author. E-mail: matejkovakristyna@seznam.cz}

${ }^{1}$ There is documentary evidence of people in this area in pre-history and Early Mediaeval Period. But it is outside the scope of this article and readers are referred to J. Prostředník's article for further information (Prostředník 2000). from capricious owners, numerous fires and wartime looting. These events necessitated frequent reconstruction of buildings, and led to changes in the original urban plan. What we are learning from current small-scale archaeological excavations is that the town is a multi-phase palimpsest of urban history, whose individual phases are often difficult to recognize and difficult to interpret.

\subsection{Knowledge from Archaeological Sources}

Although written sources can partly clarify the history of Czech towns, our understanding of towns is undoubtedly affected by the scope and quality of archaeological excavation. Systematic large-scale excavation, in particular, provides a considerable amount of archaeological material and also - albeit to a limited extent - some information about the life of the people of that time. However, no extensive excavations of mediaeval or modern Turnov have yet been carried out. The efforts of archaeologist to acquire a better understanding of the town's history have had to make do with less extensive interventions, during underground utility works, or alterations to existing buildings.

Even there, however, we managed to document some of the surface context, from which we have been able to gradually 
piece together a picture of Turnov's past. Enough small excavations have been carried out in recent decades to allow archaeologists to contribute not only to our knowledge of local structural development, but also to our understanding of the standard of living, the variety of the local crafts, and the extent of devastation caused by fires. Numerous sherds unearthed by these excavations have served only to provide dates for the excavated contexts, and were not investigated further.

\subsection{Pottery Crafts in Turnov}

Despite the increase of research interest in the topic, our present knowledge of pottery production in Turnov and vicinity remains limited. We do not know of any manufacturing facility in the town centre and excavations in the area have not yielded much. The only excavation which may have found evidence of a pottery was a furnace or kiln excavated in 1962 by M. Štěpánek in the very centre of what is now Turnov, in Trávnice Street. Unfortunately no documentation is available today and everything what we have is just oral communication. Pottery does exist but lacks context data and cannot be considered representative. The only benefit from the existence of these now essentially worthless potsherds is that they refute a later report which stated that the furnaces were used to produce red-painted pottery (Waldhauser 1980, 54).

The nearest evidence of pottery comes from the village of Pelešany about $2 \mathrm{~km}$ from Turnov. In 1996 several probable mediaeval kilns were disrupted on a terrace above the left bank of the river Libuňka, and partially documented (Prostředník 1997, 154). A large pottery assemblage uncovered at the time has not been comprehensively evaluated. Generally speaking, it is orange-coloured with red decorations and dated to the late $14^{\text {th }}$ and first half of the $15^{\text {th }}$ century. A more detailed analysis is necessary in order to integrate the material more precisely into the chronological framework.

The available written records do not offer any evidence concerning the beginnings of ceramic manufacturing in Turnov. The oldest records dating back to the Modern period note that a Master Potter's guild was established in 1570 and an Apprentices guild in 1660 (Skružný 1974, 183; 185), along with records of occasional guild related work disputes (Winter 1913, 158, 183). The co-existence of the Apprentices and Master Potter's guilds in a small vassal town suggests that there was a strong tradition of pottery-making (Skružný 1974, 181).

\subsection{Options for processing pottery from Turnov}

The considerably fragmentary pottery assemblages excavated from Turnov are fragmentary and our understanding of local production is quite difficult. The usual procedure of comparing complete assemblages was not possible as they were frequently contaminated with younger finds. Attempts to obtain valid information from the large volume of sherds led to the abandonment of - for the archaeologist - the safe haven of the human sciences, and entry into the field of the natural sciences.

This, however, is not a new approach in archaeology. The first attempts to enrich our awareness of mediaeval pottery production through laboratory analyses were made at the end of the 1960's (Nekuda and Reichertová 1968, 32; Hejdová and Nechvátal 1970). A variety of published papers are now available which try to use physical and chemical analyses to expand the boundaries of archaeological knowledge ( $c f$. Gregerová et al. 2010, 12). However, while these efforts were pursued with considerable enthusiasm in the past, we can see a certain modern scepticism amongst archaeologists. The results of these studies seldom provide clear answers to our questions and sometimes lead us to question their utility. Nevertheless, the laboratory work itself is not the core problem while there remains the persistent problem of the "communication barrier" between archaeologists and laboratory specialists.

We also cannot rely on the fact that laboratory results might significantly influence our view of Turnov's ceramics. Due to the relatively high costs of these analyses the number of samples ${ }^{2}$ analysed is limited. Each assemblage was represented by only one potsherd. For this reason we could not compare results within an assemblage - every sample is individual - and we could not obtain partial feedback from the knowledge we acquired. The main reason why we decided to conduct laboratory analysis was in an attempt to enrich the standard procedures used to process pottery. We also wanted to find out whether such analyses can, despite the small scale and high fragmentation of the assemblages shed more light on the subject.

The aim was to compare the qualitative characteristics of each pottery assemblage and discover if and how they developed over time. ${ }^{3}$ It was important to determine the approximate firing temperature and assess the basic properties of the matrix and its temper. Using laboratory analysis should also answer the question of how pottery may contribute to our knowledge of pottery production and whether pottery can be taken as an indicator of significant changes in society (e.g. by changing type of temper or preparing of ceramic mass).

But our primary research aim, despite the scarcity of samples (and the related assertion that the results cannot be considered relevant for characterizing Turnov's pottery), was to contribute to the general discussion on this topic. This experiment was needed to compare the published results which archaeologists usually receive from laboratories. As the main criterion we chose firing temperature, since values obtained by different laboratories sometimes differ a lot (about hundreds of degrees). The intention was not to point out possible errors or show that one laboratory has bad and another one better results due to used analysis or other approaches. We wanted rather to refer that many published studies brought really different results and also to contribute data from new samples.

${ }^{2}$ The laboratory analyses were funded by GA ČR 404/08/H026.

${ }^{3}$ The origin of the raw materials was not the primary target of the analyses. For that reason, no attention was paid to the geological samples. Reflections on this topic should rather be general assessments and theories. 


\subsection{Firing Process as a criteria of evaluation}

Firing is the key process in pottery production. The quality of firing undoubtedly influenced the properties of vessels. We can assume that firing could be a value criterion for ceramic products. Today it provides a valuable source of information for archaeologists, helping us to understand the level of a potter's skill in a particular workshop, at a given time. It also allows us to judge the quality of the product. Traditionally, we describe it as weak or good, or having a sandwich effect. These characteristics are relatively superficial (Kociszewski, Kruppe 1964, 173), immeasurable and partly subjective. To improve the precision of our assessment it would help to know the maximum temperature reached by a kiln during firing.

The temperature analysis results obtained by laboratory usually differ greatly between laboratories. The firing temperature range, generally accepted among Czech archaeologists and confirmed by some analysis, is usually between $600-900^{\circ} \mathrm{C}$ (Št'astná 1998, 112). Those temperatures are common for mediaeval pottery between 1200 and 1500 and considered as local production. This statement concerns e. $g$. pottery from the second half of $13^{\text {th }}$ century from the deserted mediaeval town of Sekanka (Richter 1982, 104). For post-mediaeval pottery after 1500 the temperatures should exceed $900{ }^{\circ} \mathrm{C}$. Similar temperature was stated for production of the town of Beroun between second half of $16^{\text {th }}$ and first half of $17^{\text {th }}$ century or for some sorts of pottery from the town of Sedlčany from the half of $18^{\text {th }}$ century (Dohnal, Koucký 2000, 369).

In contrast, recent studies of early mediaeval and medieval pottery from southern Poland $\mathrm{d}^{4}$, conducted by the Glass and Ceramics Faculty of the Academy of Fine Arts in Wroclaw, Poland have noted temperatures from 500 to $600{ }^{\circ} \mathrm{C}$. It is only with glazed ceramic and stove tiles that higher than normal temperatures of 800 to $850{ }^{\circ} \mathrm{C}$, are reported (Stoksik 2007, 217, 324).

Regardless of questions being asked about whether early mediaeval pottery was actually fired at $500{ }^{\circ} \mathrm{C}$ (Macháček 2001, 21), analyses conducted in Moravia (Dvorská, Poláček 1995, 198) and elsewhere in Europe (Bystroyem 1955, 252; Hulthen, Brorsson 2007; in a summary Brather 2002,48) show similar results. In Bohemia however, we find significantly higher temperatures, reaching up to $1,000^{\circ} \mathrm{C}$ (Hanykýř et al. $2002,161)$. The relatively significant divergence between results led to the idea of asking the Wroclaw laboratory for an analysis of Bohemian pottery samples for comparison.

\section{Methods}

\subsection{Preparation of Samples}

Turnov $^{5}$ pottery has been sufficiently studied to provide a basic outline of the most common shapes and types of vessels. In

${ }^{4}$ Most of the analysed samples come from the area of Lower Silesia.

${ }^{5}$ The pottery from the Turnov is dealt with in a dissertation which is being produced at the Institute for Prehistory and Early Mediaeval History at Charles University in Prague. the first phase, the sherds were divided into five very general groups of pottery. Hopefully there will be possible to create more precise groups in the future, but current situation unable to do so. Those groups served to provide basic information on the development of pottery in Turnov. They also represent an overview of local pottery production, or at least of the range of pottery types used locally, because we exactly still do not know what pottery was produced right here.

Within these groups, individual sherds were then chosen which were suitable for scientific analysis. The samples were described on the basis of macroscopic observation, documented and submitted for laboratory processing. The samples were deliberately given no labels, dates or descriptions before despatching them to the laboratory in order to avoid any possible influence over the results of the analyses.

With respect to the intention to compare the resulting values with those obtained in Poland recently, the same procedure as with the previous works (see Tab 1; $c f$. Rzeźnik, Stoksik 2004) was maintained in the lab. While each of these methods is used for a specific purpose, their interdependence is inevitable. It allows for the correction of possible errors and greater precision in the results. The author does not consider herself to be competent enough to discuss the suitability of the methods used. The results of the analyses are therefore presented here without critical evaluation.

\subsection{Pottery Assemblages and Their Primary Properties}

\subsubsection{Pottery from the town's foundation (Sample A)}

This pottery is associated with the period during and just after the foundation of the town and includes coarser ware in ochre, ochre-grey, grey-brown or greyish. On the rough surface there are numerous macroscopic grains of non-plastic components (mostly quartz sand), 1-2 $\mathrm{mm}$ in size and occasionally larger. We have no supporting data for date and accept a wide interval between the latter half of the $13^{\text {th }}$ century and the end of the $14^{\text {th }}$ century. The most common items are pots without handle and bowls. Decoration is limited to incised horizontal lines and simple wheel pressing. This pottery was mostly manufactured using a coil construction and wheel finishing, and predominantly fired in an oxidizing atmosphere.

\subsubsection{Red Painted Pottery (Sample B)}

This pottery is easy to recognise due to its whitish, creamy yellow to pale orange colour. However, it is difficult to apply a uniform scale to describe its properties. In some cases there is a rough surface structure together with numerous non-plastic components (grains sized 1-2 mm), whereas on other items the structure is much smoother with a less visible temper. Its occurrence in Turnov is associated mostly with the $14^{\text {th }}$ century, but earlier origins cannot be discounted. In the $15^{\text {th }}$ century it acquired a late mediaeval morphology.

The prevailing vessel forms are pots and jars, while other forms, such as lids and bowls, are rare. Decoration consists of red paint with simple lines and occasionally also grooved spirals and incised horizontal lines. The vessels manufactured 


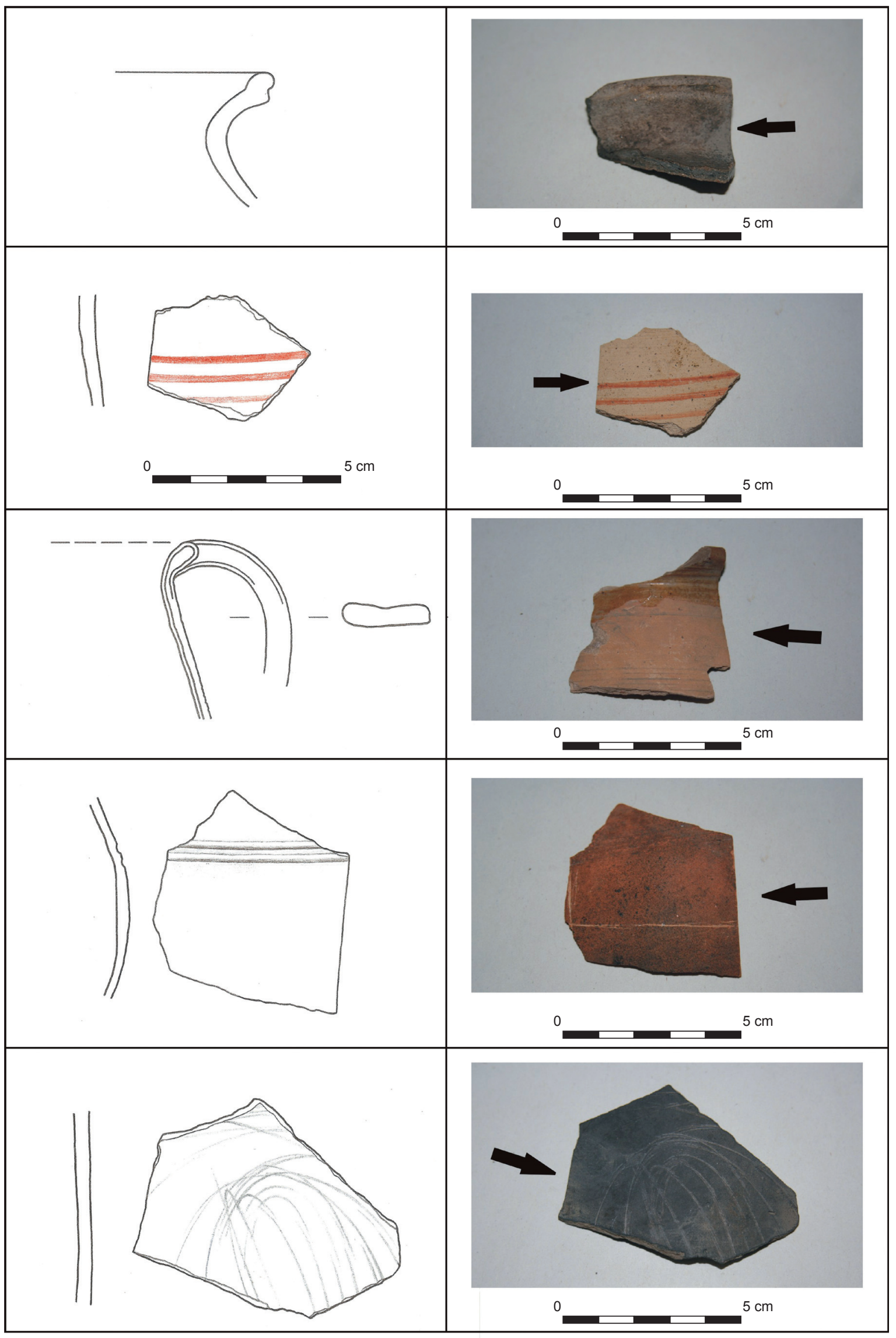

Figure 1. Documentation for samples A - E (from above; drawings by V. Čermák; photo by K. Matějková). 
Table 1. Overview of the analysis made by the Wroclaw laboratory.

\begin{tabular}{ll}
\hline \multicolumn{1}{c}{ Methods } & \multicolumn{1}{c}{ Overview of Analyses } \\
\hline Microscopic analysis (+ thin section) & $\begin{array}{l}\text { Outputification of mineral composition of samples and technology } \\
\text { of making vessels (ceramic classes) }\end{array}$ \\
\hline X-ray diffraction analysis (XRD) & $\begin{array}{l}\text { identification of mineral composition of matrix; determination } \\
\text { of crystalline phases }\end{array}$ \\
\hline Differencial thermal analysis (DTA, TG, DTG) & determination of firing temperatures \\
\hline "Archimedes method" (weighing samples immersed in the water) & determination of properties of samples (water absorption) \\
\hline
\end{tabular}

in a coil construction with underscatter and later were also wheel-thrown (as shown by marks of cutting from the wheel on the bottom of the vessels). The pottery is usually fired in an oxidizing atmosphere.

\subsubsection{Red Ware (Sample D)}

This brownish, orange to brick-red coloured ware represents the transition between mediaeval and post-mediaeval pottery. Some, mostly thick-walled, examples are rough-surfaced due to protruding temper of about $1-4 \mathrm{~mm}$ in size. Other examples have a gritty structure with small non-plastic components of up to $1 \mathrm{~mm}$. This pottery originated in the $15^{\text {th }}$ century though earlier dates cannot be discounted. Even more complicated is the question of ending up, since Red Ware could have persisted long into the mediaeval period especially between lower social classes. It seems to be prevalent from the mid- $15^{\text {th }}$ century until the first half of the $16^{\text {th }}$ century.

Most vessels are medium-sized pots with a handle. Less frequent items include deep bowls, jars, lids and large bowls with horizontal handles. Decoration is quite simple and includes incised horizontal lines, white painting, or wheel pressing of the upper parts of the vessel. Deep bowls are decorated with ordinary plastic mouldings. The bottoms were usually cut out, which - together with the subtlety and the regularity of the walls - we consider being a sign of more advanced techniques, such as the use of a fast wheel. The colouring indicates that it was fired in an oxidizing atmosphere.

\subsubsection{Grey Reduction Fired Ware (Sample E)}

Like the previous group this whitish-grey, grey or dark grey ware, fired in a reduction atmosphere, stems from a mediaeval tradition. It begins to spread in the $15^{\text {th }}$ century when the first coarse-grained sherds with wheel-pressed decoration appear. In the latter half of the $15^{\text {th }}$ century and first half of the $16^{\text {th }}$ century we find thin-walled specimens with a gritty structure, with grains between 1 and $1.5 \mathrm{~mm}$, or with a smooth polished surface. This was later replaced with smooth smoked ware of the highest optical quality with no visible temper. The smoked ware, also found among the selected samples, was long popular even into the $19^{\text {th }}$ century in some areas.

In all periods we most often come across higher oviform pots with quite short handles. Lids and deep bowls are also common. Conversely, jugs are relatively rare. In older periods decoration consists of the standard range of wheelpressed strips, and the occasional incised horizontal lines or polishing. The advanced production features the smoking process and polishing, mostly with oviform motifs. Based on technological features we presume the pottery was manufactured on a fast wheel.

\subsubsection{Glazed Pottery (Sample C)}

Glazed pottery is post-mediaeval. Quality is improved by glazing. Body colour ranges from whitish, ochre and pale orange to red-orange. Non-plastic components are either not apparent or appear only randomly on the surface (1-2 mm in size). In the Turnov ceramic assemblage glazed sherds are significantly more frequent during the $16^{\text {th }}$ century, when they gradually begin to appear in higher numbers. It is possible that the first glazed vessels were made as early as the late $15^{\text {th }}$ century. However, the current assemblage does not support this interpretation.

The most frequent type of vessels are pots with a single handle, followed by pans with three legs (tripod), jars, deep bowls, shallow bowls or plates, and pans. The decorative motifs are mostly grooved spirals and incised or red-painted horizontal lines on the upper part of the vessel. Clay painted ware or glaze dripping occurs later. The aesthetics of these types of decoration are enhanced by a white englobe. The pottery was mainly manufactured using a fast wheel. Given the body colour the firing process was in an oxidizing atmosphere.

\subsection{Selection of Samples for Scientific Analysis}

The selection of sample was based on the groups described above. Special care was taken to select fragments of vessels from similar parts (edge or upper parts of the bulge) to eliminate any possible bias, which might occur given the potential variety in production techniques and material that might be found in different parts of a vessel (Zavřel, Žegklitz 1990, 112). The selected samples were documented with photos and drawing (Figure 1), and subsequently described on the basis of macroscopic observation (Table 2). The style of macroscopic description was derived from Stoksik (Stoksik 2007).

\section{Results}

\subsection{Thin Sections}

Thin sections are thin slices of ceramic material taken from sherds (Taylor 1960). They are studied under a polarizing 
Table 2. Description of samples after the macroscopic observation.

\begin{tabular}{|c|c|c|c|c|c|}
\hline \multicolumn{6}{|c|}{ Macroscopic determination of samples } \\
\hline Properties & Sample A & Sample B & Sample C & Sample D & Sample E \\
\hline Find location & Český ráj square & $\begin{array}{l}\text { Český ráj square } \\
\text { (south-west part) }\end{array}$ & Mariánské square & $\begin{array}{c}\text { Mariánské náměstí } \\
\text { square }\end{array}$ & $\begin{array}{c}\text { Sobotecká street } \\
\text { (nr. 450) }\end{array}$ \\
\hline Inventory number & $169 / 95$ & $44 / 93$ & $55 / 93$ & $56 / 93$ & $\mathrm{~T}-79$ \\
\hline Type of vessel & pot & pot/jug & pot & pot/jug & undetermined \\
\hline Surface & gritty - rough & mildly rough & soft & gritty & soft \\
\hline Matrix - temper & $\begin{array}{c}\text { sand/quartz (til } 0,5 \\
\mathrm{~mm})\end{array}$ & $\begin{array}{c}\text { sand/quartz (til } \\
1 \mathrm{~mm})\end{array}$ & imperceptible & $\begin{array}{l}\text { sand/quartz (cca } \\
0,5-1 \mathrm{~mm})\end{array}$ & imperceptible \\
\hline Colour inside & grey-brown & creamy yellow & $\begin{array}{l}\text { transparent glaze } \\
\text { (yellow) }\end{array}$ & orange & grey-black \\
\hline Colour outside & ochre-grey & creamy yellow & ochre; partly glazed & orange & grey \\
\hline $\begin{array}{l}\text { Colour of fraction } \\
\text { (inside, middle, outside) }\end{array}$ & $\begin{array}{l}\text { ochre-grey/ochre/ } \\
\text { grey }\end{array}$ & creamy yellow & ochre & orange & $\begin{array}{l}\text { brown/lightgrey/ } \\
\text { brown }\end{array}$ \\
\hline Rim diameter & $15 \mathrm{~cm}$ & immeasurable & $10 \mathrm{~cm}$ & immeasurable & immeasurable \\
\hline Bottom diameter & immeasurable & immeasurable & immeasurable & $8 \mathrm{~cm}$ & immeasurable \\
\hline Wall width & $3 \mathrm{~mm}$ & $4-5 \mathrm{~mm}$ & $3 \mathrm{~mm}$ & $3-4 \mathrm{~mm}$ & $7-10 \mathrm{~mm}$ \\
\hline Rim width & $6-7 \mathrm{~mm}$ & immeasurable & $5 \mathrm{~mm}$ & immeasurable & immeasurable \\
\hline Ornamentation & $\begin{array}{c}\text { engraved horizontal } \\
\text { lines }\end{array}$ & $\begin{array}{l}\text { red painted/lines } \\
\text { and waves }\end{array}$ & $\begin{array}{c}\text { engraved horizontal } \\
\text { lines }\end{array}$ & $\begin{array}{c}\text { engraved horizontal } \\
\text { lines }\end{array}$ & polished/egg-form \\
\hline Production traces & $\begin{array}{c}\text { wheel/ } \\
\text { turnable finishing }\end{array}$ & $\begin{array}{l}\text { turning/smoothed } \\
\text { by wooden tool }\end{array}$ & turning & $\begin{array}{l}\text { turning/cut away } \\
\text { bottom }\end{array}$ & turning \\
\hline
\end{tabular}

Table 3. Mineralogy of the samples on the basis of microscopic analysis.

\begin{tabular}{cccccccc}
\hline \multirow{2}{*}{$\begin{array}{c}\text { Samples } \\
\text { signification }\end{array}$} & Quartz & $\begin{array}{c}\text { Feldspar/ } \\
\text { plagioclase }\end{array}$ & $\begin{array}{c}\text { Biotite/ } \\
\text { muscovite }\end{array}$ & Pyroxen & $\begin{array}{c}\text { Carbonaceus } \\
\text { substances/ graphite }\end{array}$ & $\begin{array}{c}\text { Rocks shards (with } \\
\text { quartz and mica) }\end{array}$ & Calcite \\
\hline $\mathrm{A}$ & +++ & +++ & + & + & $(+)$ & + & + \\
$\mathrm{B}$ & +++ & + & + & + & $(+)$ & + & - \\
$\mathrm{C}$ & +++ & $(+)$ & + & - & $(+)$ & + & - \\
$\mathrm{D}$ & +++ & ++ & + & + & + & $(+)$ & - \\
$\mathrm{E}$ & +++ & ++ & + & - & + & - & - \\
\hline
\end{tabular}

$(+++$ frequent,++ middle high, + low, $(+)$ trace content, - not contained $)$

Table 4. The non-plastic components in matrix (by grain size).

\begin{tabular}{ccccccc}
\hline \multirow{2}{*}{$\begin{array}{c}\text { Samples } \\
\text { signification }\end{array}$} & \multicolumn{2}{c}{ Coarse component } & \multicolumn{2}{c}{ Medium component } & \multicolumn{2}{c}{ Soft, clay component } \\
\cline { 2 - 7 } & Average size of grains & $\mathbf{( \% )}$ & Average size of grains & $\mathbf{( \% )}$ & Average size of grains & $\mathbf{( \% )}$ \\
\hline A & $1.0-1.5 \mathrm{~mm}$ & 20 & $0.05-0.3 \mathrm{~mm}$ & 20 & $<0.05 \mathrm{~mm}$ & 60 \\
$\mathrm{~B}$ & $0.3-1.0 \mathrm{~mm}$ & 30 & $<0.2 \mathrm{~mm}$ & 20 & $<0.03 \mathrm{~mm}$ & 50 \\
$\mathrm{C}$ & - & - & $<0.05 \mathrm{~mm}$ & 45 & $<0.01 \mathrm{~mm}$ & 55 \\
$\mathrm{D}$ & $1.0-1.5 \mathrm{~mm}$ & 3 & $0.05-1.0 \mathrm{~mm}$ & 27 & $<0.01 \mathrm{~mm}$ & 70 \\
E & $\geq 1.5 \mathrm{~mm}$ & 2 & $0.1-0.2 \mathrm{~mm}$ & 58 & $<0.05 \mathrm{~mm}$ & 40 \\
\hline
\end{tabular}

microscope to determine the mineral composition of the matrix (kind of minerals, particle orientations, size, shapes and locations). One of the most useful outputs is granulometry (Rice 2005, 379). However, due to small size or the general homogeneity of the material, some minerals could not be clearly identified. The results (Figure 2, Table 3 - the petrographic composition, Table 4) of this analysis must therefore be combined with data from other methods including X-ray diffraction analysis (XRD).

\section{2 $\mathrm{XRD}^{6}$}

XRD uses X-rays (Zussman 1977) of known wavelengths for the registration and identification of crystalline phases and provides basic information about their contents (Table 5). This method is destructive. The small piece of sample is

${ }^{6}$ The analysis was made using a diffractograph with a lamp with a $\mathrm{Co}$ and $\mathrm{Fe}$ screen within the range of $2 \Theta=4^{\circ}$ to $75^{\circ}$. 

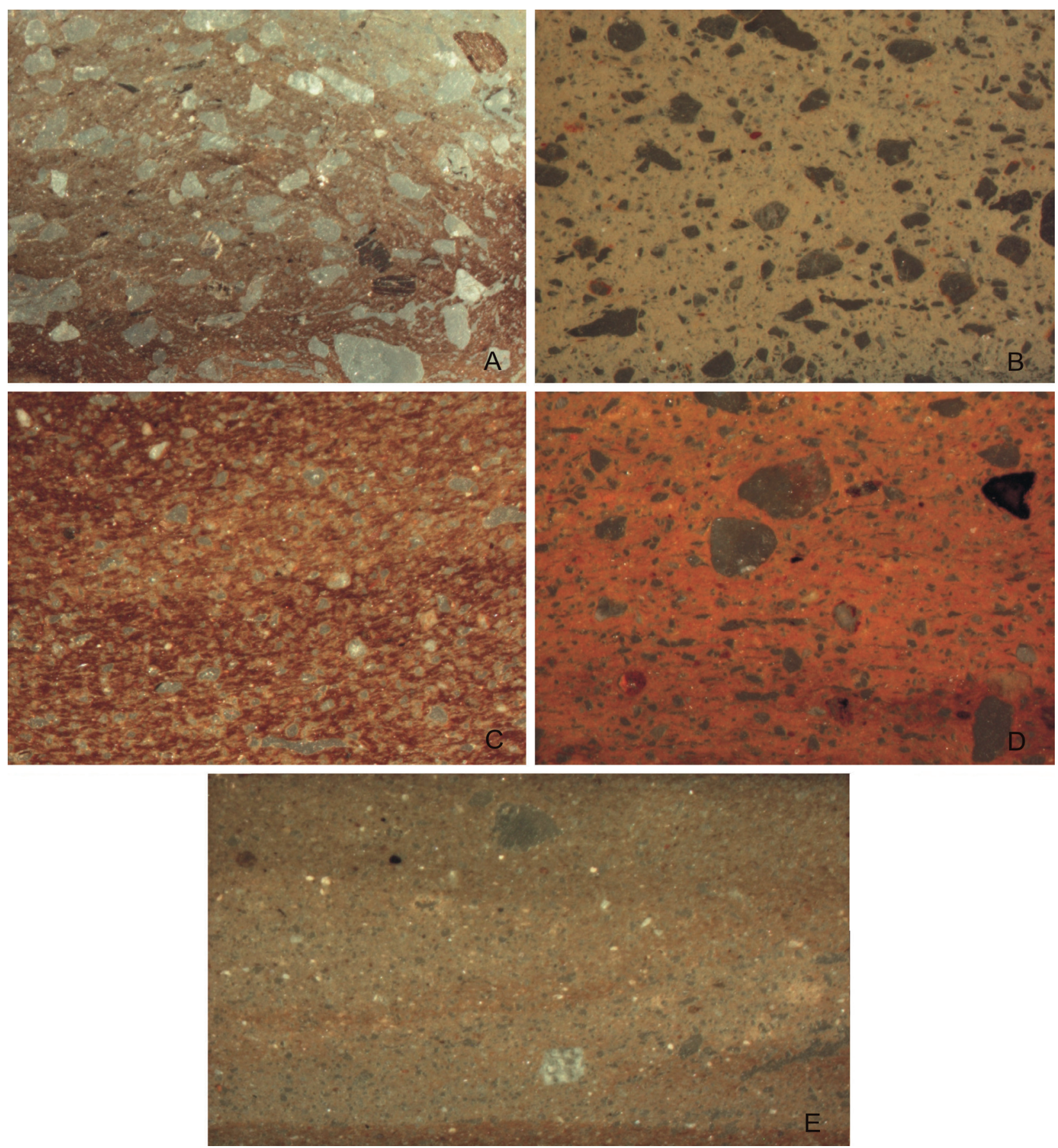

Figure 2. Microphotography of thin sections of samples A-E (45× enlarged; photo by H. Stoksik).

ground to a fine powder and form into a thin rod. It is quite commonly used in analysis of ceramic properties. However, due to possible errors (the sensitivity of the powder XRD depends on the type of minerals concerned) it is useful to correlate the XRD data with the results of other methods (Gregerová et al. 2010,38). XRD output is in the form of a diffractogram (Figure $3 \mathrm{a}-\mathrm{e})^{7}$.

${ }^{7}$ In the case $\mathrm{a}, \mathrm{b}, \mathrm{c}$ the diffractogram has shown just a presence of muscovite and no illite. The reason is, that the polymorphological changes in the samples has already started.

\subsection{DTA $^{8}$}

Differential thermal analysis (DTA; e.g. Grim 1968, fig. 9-30) is used to study how individual minerals or substances change during a gradual increase in temperature (sample is heated to approximately $1,000{ }^{\circ} \mathrm{C}$ ). As with microscopy and XRD this method is not without its difficulties when used on historic

${ }^{8}$ The analysis was made using a derivatograph within the temperature range of $25{ }^{\circ} \mathrm{C}$ to $970{ }^{\circ} \mathrm{C}$ and the heat-up speed of $10{ }^{\circ} \mathrm{C} / \mathrm{min}$. Samples $400 \mathrm{mg}$ in weight were analysed. The TG curve shows a loss of mass during heating up of sample from 20 to $1,000{ }^{\circ} \mathrm{C}$; it is written in Table 6 . 


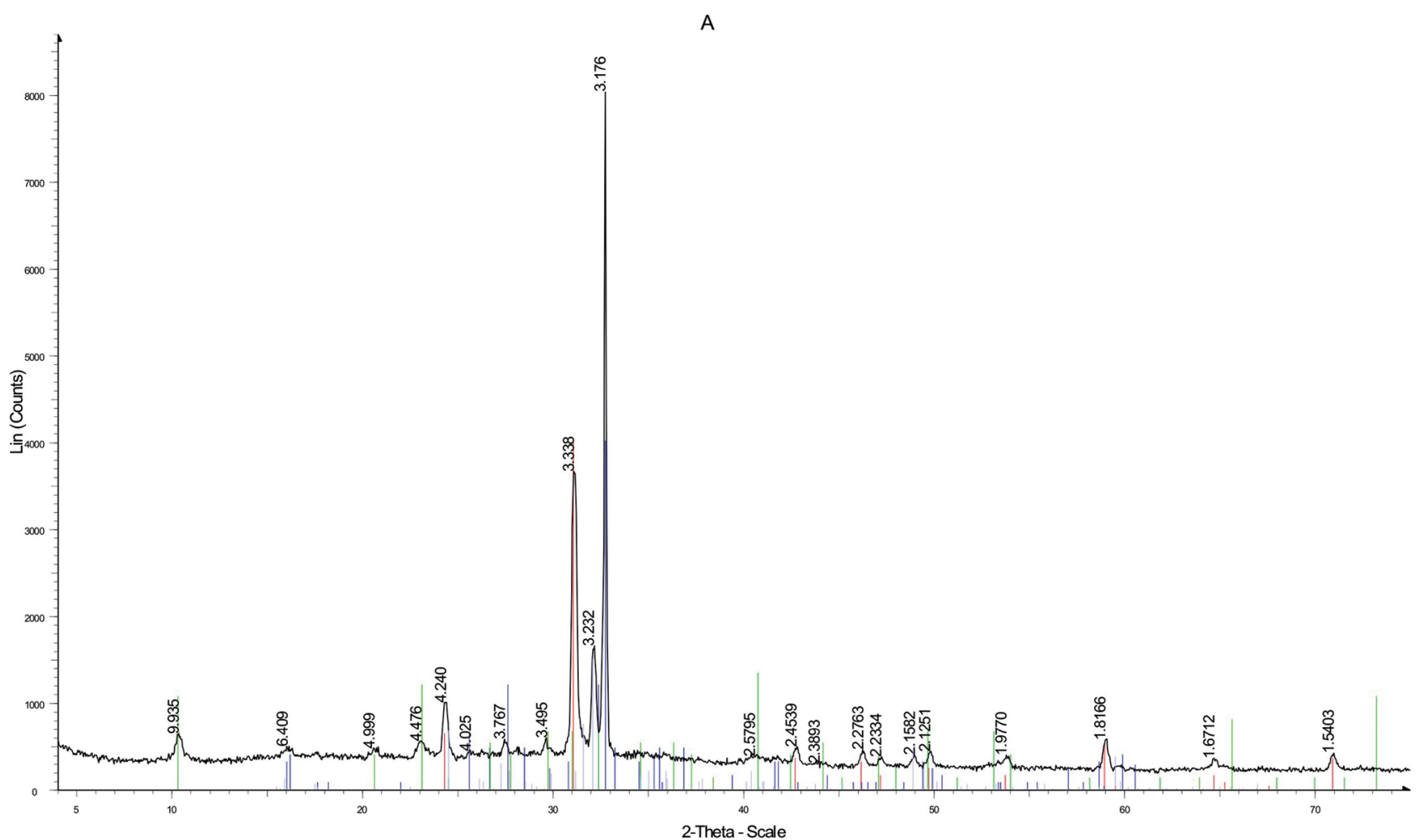

四 EFile: 4940. raw - Type: 2 Th/Th locked - Start: $4.000^{\circ}$ - End: $75.000^{\circ}$ - Step: $0.040^{\circ}$ - Step time: 1.0 s - Temp.: $27.0^{\circ} \mathrm{C}$ - Time Started: 3 s - 2-Theta: $4.000^{\circ}$ - Theta: $2.000^{\circ}$ - - Phi: $0.000^{\circ}$ - - - - Aux1: 0.000 - Aux:

Operations: Import

10-0393 (*) - Abite, disordered - Y: $50.00 \%-$ Na(Si3AI)O8 - d x by: 1.000 - WL: 1.78897

W. 03-0849 (D) - Muscovite - Y: $16.67 \%$ - HAK2(A, Fe)6Si6O24 - $d x$ by: 1.000 - WL: 1.78897

19-0932 (I) - Microdine, intermediate - Y: $18.75 \%$ - KASSi308 - $d$ x by: 1.000 - WL: 1.78897

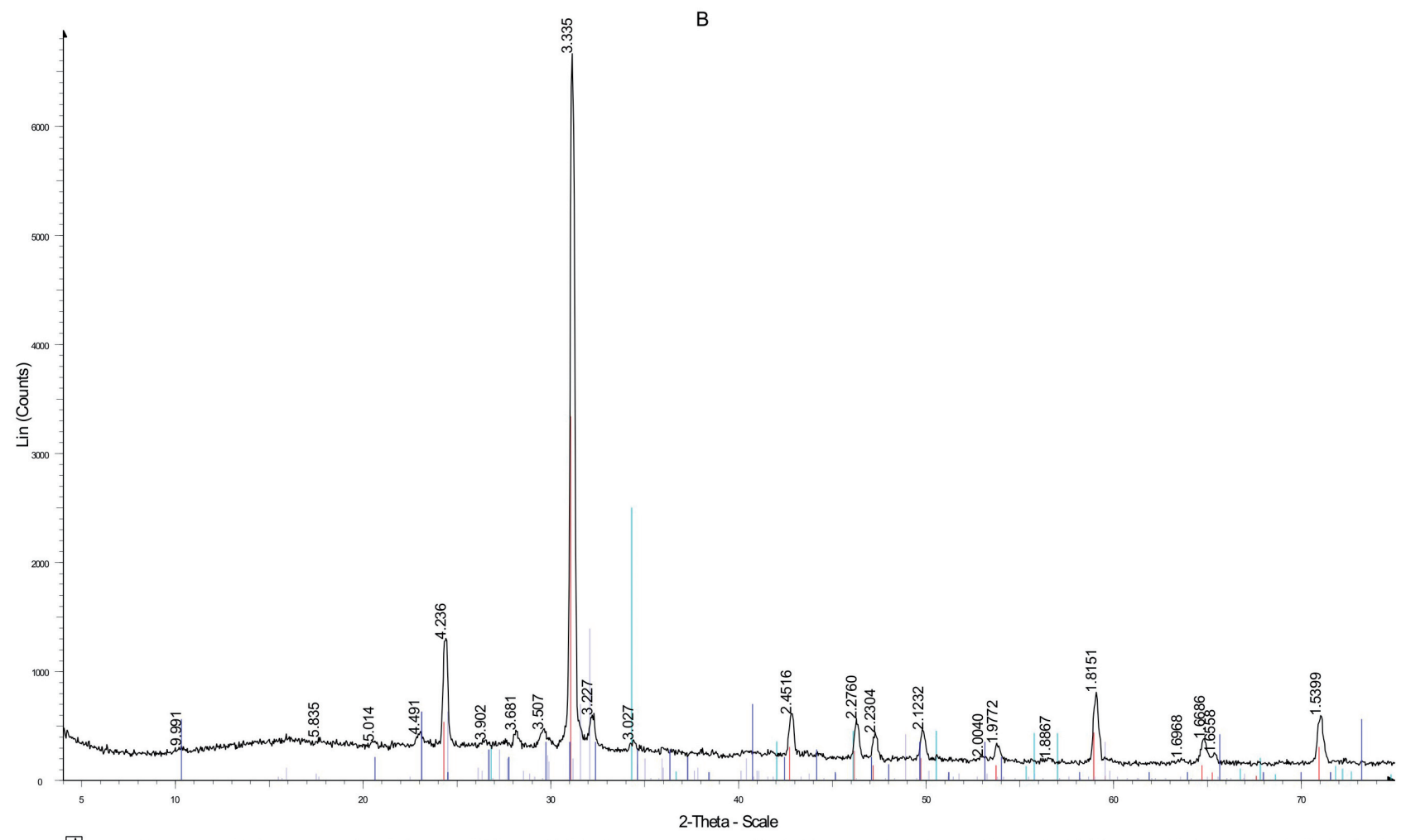

WT- File: 4941 .raw - Type: 2 Th $T$ Th locked - Start: $4.000^{\circ}$ - End: $75.000^{\circ}$ - Step: $0.040^{\circ}$ - Step time: 1.0 s - Temp.: $27.0^{\circ} \mathrm{C}$ - Time Started: 8 s - 2-Theta: $4.000^{\circ}$ - Theta: $2.000^{\circ}$ - - Phi: $0.000^{\circ}$ - - - - Aux1: 0.000 - Aux2: 0.000

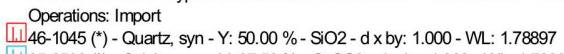

1.1. 05-0586 (*) - Calcite, syn - Y: $37.50 \%$ - CaCO3 - d x by: 1.000 - WL: 1.78897

1. 19-0932 (I) - Microcline, intermediate - Y: $20.83 \%$ - KASSi308 - $\mathrm{d}$ x by: 1.000 - WL: 1.78897

Wل 03-0849 (D) - Muscovite - Y. $10.42 \%$ - H4K2(Al Fe)6Si6O24 - d x by 1.000 - WL- 178897

Figure 3a, b. Diffractograms (a - sample A, b - sample B). 


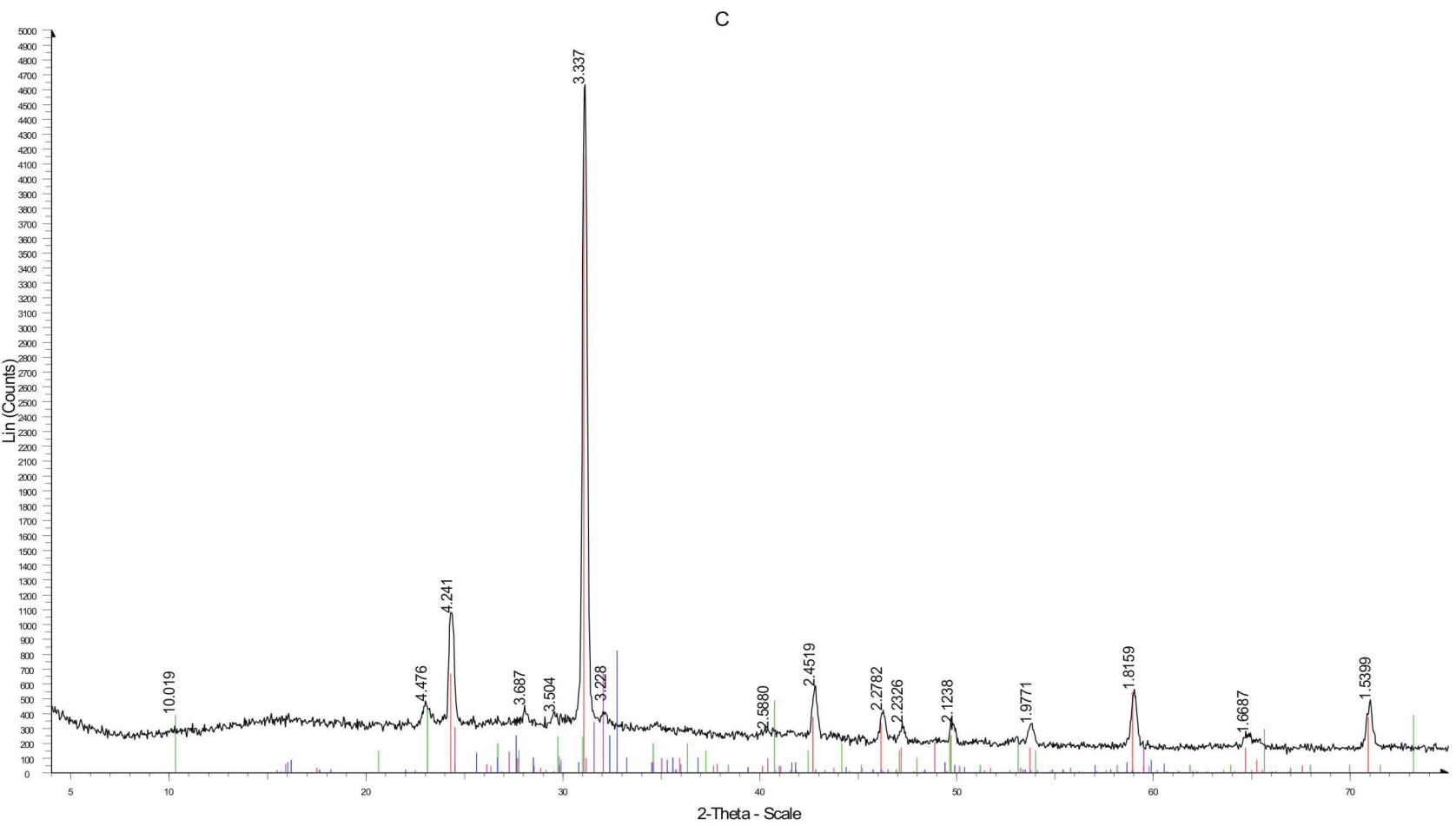

四 - File: 4942 .raw - Type: 2 TWTh locked - Start: $4.000^{\circ}$ - End: $75.000^{\circ}$ - Step: $0.040^{\circ}$ - Step time: 1.0 s - Temp: $27.0^{\circ} \mathrm{C}$ - Time Started: $3 \mathrm{~s}$ - 2-Theta: $4.000^{\circ}$ - Theta: $2.000^{\circ}$ - - Phi: $0.000^{\circ}$ - - - - Aux1: 0.000 - Auxz: 0.000

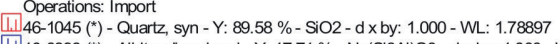

1.10-0393 (*) - Albite, disordered - Y: $17.71 \%$ - Na(Si3A)O8 - $d x$ by: 1.000 - WL: 1.78897

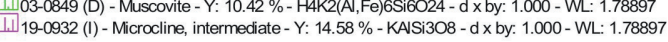
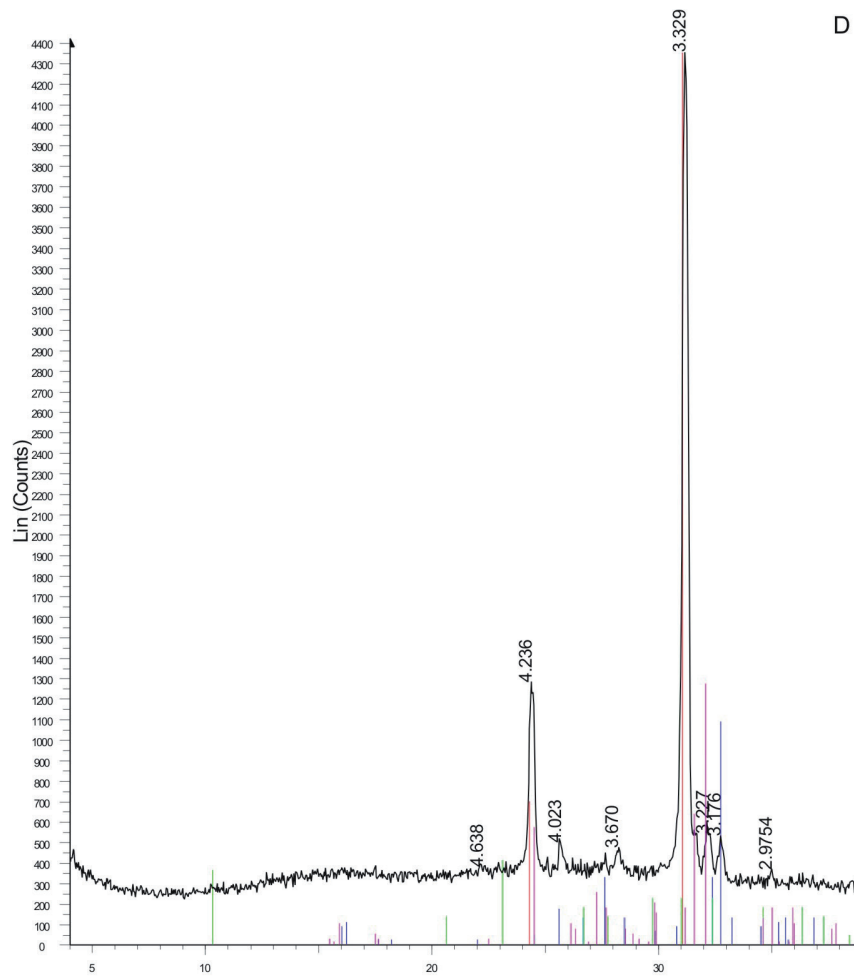

W - File: 4943. raw - Type: 2 Th/Th locked - Start: $4.000^{\circ}$ - End: $75.000^{\circ}$ - Step: $0.040^{\circ}$ - Step time: 1.0 s - Temp: $27.0^{\circ} \mathrm{C}$ - Time Started: 3 s - 2-Theta: $4.000^{\circ}$ - Theta: $2.000^{\circ}$ - - Phi: $0.000^{\circ}$ - - - - Aux1: 0.000 - Aux2: 0.000 Operations: Import

W.16-1045 (*) - Quart, syn - Y: $100.00 \%$ - SiO2 - d x by: 1.000 - WL: 1.78897

1010-0393 (*) - Albite, disordered - Y: $25.00 \%$ - Na(Si3A)O8 - d x by: 1.000 - WL: 1.78897

W.103-0849 (D) - Muscovite - Y: $10.42 \%$ - HAK2(Al, Fe)6Si6O24 - d x by: 1.000 - WL: 1.7889

W. 19-0932 (I) - Microcline, intermediate - Y: 29.17\% - KASi3O8 - $d$ x by: 1.000 - WL: 1.78897

Figure 3c, d. Diffractograms (c-sample C, d-sample D). 


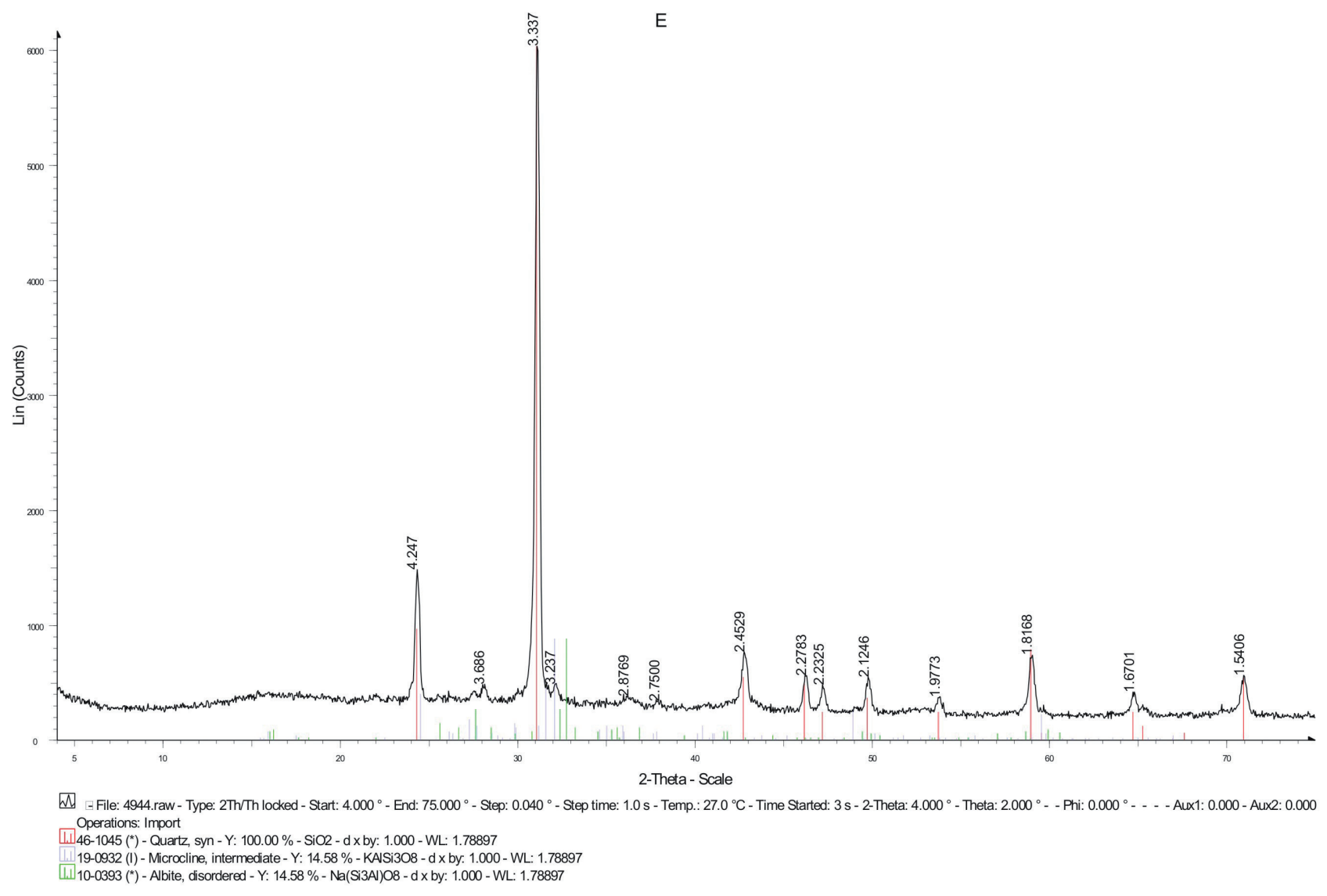

Figure 3e. Diffractograms (e-sample E).

Table 5. Recognized mineralogical phases in the selected samples.

\begin{tabular}{cl}
\hline $\begin{array}{c}\text { Samples } \\
\text { signification }\end{array}$ & $\begin{array}{c}\text { Crystalline phases } \\
\text { recognized in samples }\end{array}$ \\
\hline A & a) Quartz \\
& b) Microcline \\
c) Albite & d) Muscovite \\
\hline B & a) Quartz \\
& b) Microcline \\
& c) Calcite \\
d) Muscovite \\
\hline C & a) Quartz \\
& b) Microcline \\
& c) Albite \\
d) Muscovite \\
\hline D & a) Quartz \\
& b) Microcline \\
& c) Albite \\
& d) Muscovite \\
\hline & a) Quartz \\
& b) Microcline \\
c) Albite
\end{tabular}

Table 6. Approximate firing temperatures after differential thermal analysis.

\begin{tabular}{|c|c|c|}
\hline $\begin{array}{c}\text { Samples } \\
\text { signification } \\
\end{array}$ & $\begin{array}{c}\text { Loss on weight } \\
{[\%]} \\
\end{array}$ & $\begin{array}{l}\text { Estimated firing } \\
\text { temperature }\left[{ }^{\circ} \mathrm{C}\right]\end{array}$ \\
\hline $\mathrm{A}$ & 7.27 & 650 \\
\hline B & 1.33 & 700 \\
\hline $\mathrm{C}$ & 3.8 & 720 \\
\hline $\mathrm{D}$ & 1.34 & 800 \\
\hline $\mathrm{E}$ & 1.33 & 660 \\
\hline
\end{tabular}

Table 7. Measuring of water absorption - results.

\begin{tabular}{cc}
\hline Sample signification & Absorbability [\%] in water \\
\hline A & $13.60 \%$ \\
B & $14.57 \%$ \\
C & $16.02 \%$ \\
D & $10.47 \%$ \\
E & $16.61 \%$ \\
\hline
\end{tabular}

ceramics. DTA is useful for low to midrange firing temperatures. That is why there are doubts regarding the suitability of the method for determining the types of minerals in the matrix of mediaeval and post-mediaeval pottery, due to the relatively high temperatures which are traditionally expected. For temperatures between $900-1,000{ }^{\circ} \mathrm{C}$ DTA is not useful. In our case DTA has served primarily to determine the firing temperature of the 


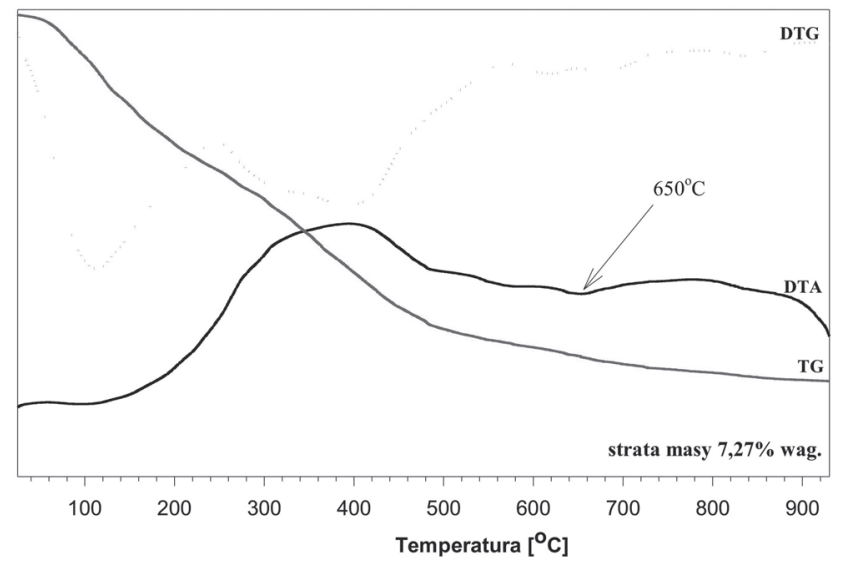

C

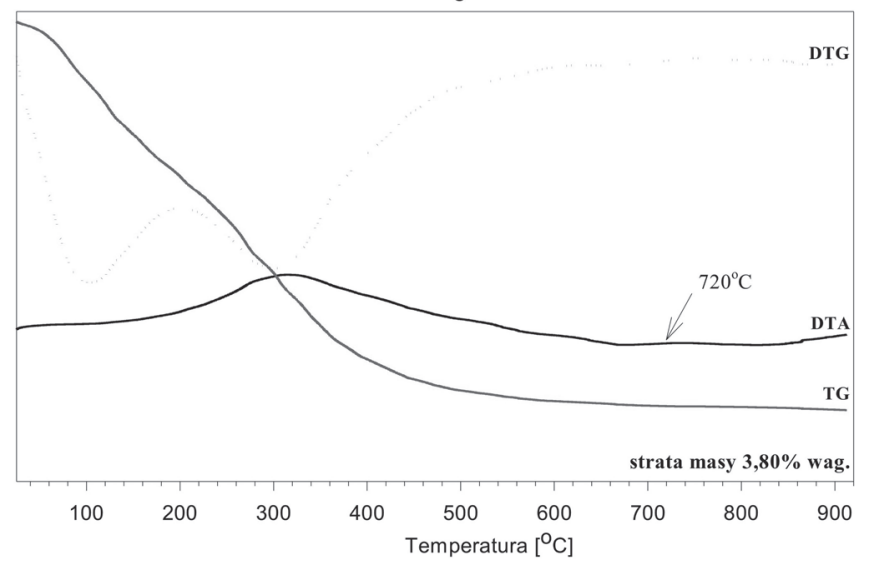

B

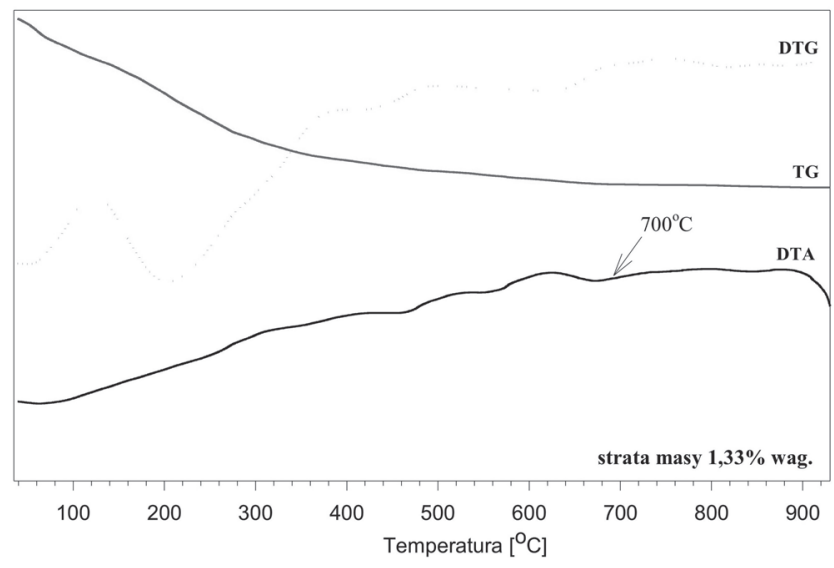

D
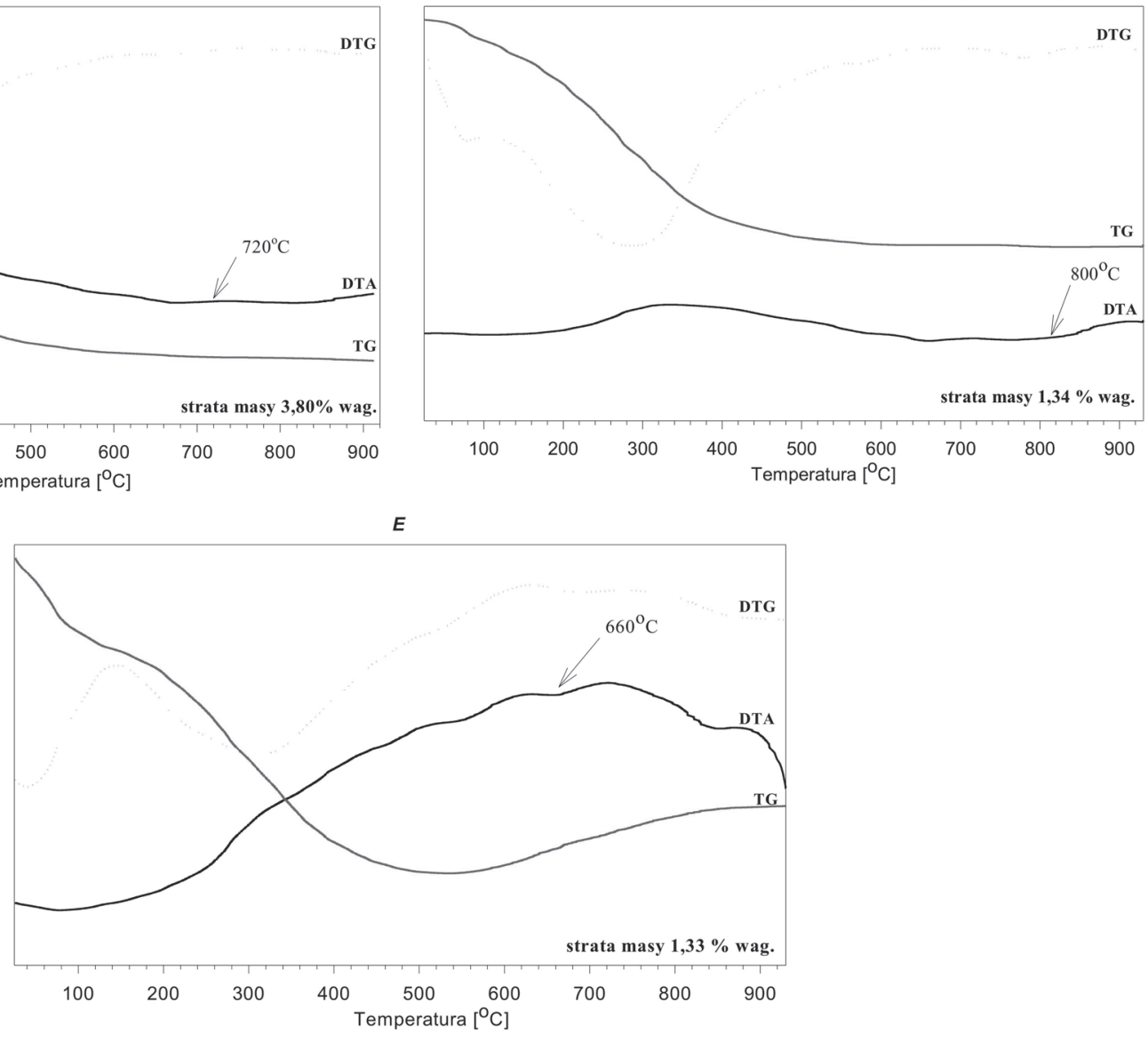

Figure 4. Thermograms ( $\mathrm{a}$ - sample A, b-sample B, c-sample C, d-sample D, e-sample E).

analysed samples, together with latter mentioned analyses. The results were evaluated on the basis of a thermogram (Figure $4 \mathrm{a}-\mathrm{e})$, where it is demonstrated by a loss of mass, together with endothermic and exothermic reactions (see Table 6).

\subsection{Archimedes Method}

For a more comprehensive understanding of the properties of pottery from Turnov, the Archimedes method was used. This involves weighing samples (which were dried under temperature of $110{ }^{\circ} \mathrm{C}$ ) immersed in water and, after another drying, determining their water absorption from the differences of their weight. This provides us with basic information concerning the vessels and their possible use, and also expands our knowledge about the quality of the firing process and the matrix. The higher the results are, the lower quality of firing process is expected (Table 7).

\section{Evaluation}

The analyses described above allowed us to evaluate the general character of the samples. As mentioned, due to the 
low number of samples we could not generalise the laboratory results to the all the various assemblages. In this case the analysis served primarily for mutual comparison between pottery samples of different periods and material. Some outcomes were assumed as early as the stage of macroscopic observation, though some laboratory tests led unexpectedly to different conclusions.

All samples had more or less the same mineralogical composition commonly found in most pottery clays and non-plastic raw materials (Kociszewski, Kruppe 1964, 165; Hanykýř, Maryška, Profantová 2005, 156-158). Differences were apparent in quantity (Table 3) and granulation (Table 4); a finding which diverges from macroscopic observations. The most striking differences in the coarseness of the temper ${ }^{9}$ are seen in sample $\mathrm{C}$ (glazed pottery), and led us to assume that it may be a ceramic of foreign origin or that it falls within the production tradition of later and more advanced stages of post-mediaeval pottery.

XRD confirmed the results of most previous observations. Sample B indicated the presence of calcite which was not found in microscopic analysis. DTA identified a relatively wide range of firing temperatures. The most surprising result was the low temperature firings used in sample E, which is otherwise of high quality to the eye. DTA results regarding the firing process correspond with the findings of the Archimedes method used to determine the water absorption of individual samples.

\subsection{Sample A}

Sample A is Turnov's oldest piece of pottery, based on site stratigraphy. However, its properties, as identified in laboratory analyses, were not entirely consistent with our assumptions concerning technical development. Its low water absorption $(13.6 \%)^{10}$ was rather surprising, especially considering the fact that the sample also showed the lowest firing temperature of all the samples analyzed $\left(650{ }^{\circ} \mathrm{C}\right)$. The firing atmosphere was oxidising neutral. ${ }^{11}$

Naturally sorted sand (perhaps river sand) was used as temper. Smoothed grains were most noticeable in the rough portion (Table 4). The reddish colour of the soft portion indicates the presence of iron compounds. The nature of mica flakes in this sample proves that the vessel was previously used for heating or cooking. The methods of firing and manufacturing are in an older production style, typical to early mediaeval pottery, but the morphology and thin walls suggest that it was made later than in the first half of $13^{\text {th }}$ century.

\footnotetext{
${ }^{9}$ The issues of natural and artifical temper in the ceramic matter was not dealt with in these analyses.

${ }^{10}$ It was low in comparison with the other samples analysed. Otherwise it is comparable to, for example, the results of analyses made on early mediaeval pottery from Bohemia ( $c f$. Hanykýř, Maryška and Profantová 2005, 156).

${ }^{11} \mathrm{At}$ the start of the firing there was an oxidizing atmosphere which changed to neutral at the end. This is proven by the colouring of the sherd on the fracture which appears in two or three different shades.
}

\subsection{Sample B}

Sample B is red-painted pottery. In the geographic area of our interest we consider it to be partially contemporary with the previous style. However, the sample comes from a heterogeneous assemblage with a date range between the $14^{\text {th }}$ and $15^{\text {th }}$ centuries and cannot be fully used for comparison. Sample B reflects an older manufacturing tradition (underscatter, embedded bottom). On the other hand, at first sight it seems to be of higher quality than sample A. This aspect would confirm the use of raw materials with greater plasticity and also oxidizing firing at temperatures of around $700{ }^{\circ} \mathrm{C}^{12}$. Nevertheless, it does not surpass the standard of production as found in sample A. On the contrary, despite the higher firing temperature, a greater degree of water absorption (14.75\%) was identified. In the medium and coarse portions (Table 4) quartz grains are prevalent and are lightly to moderately smoothed. The dark brown colouring of the fine portion indicates the presence of iron or manganese compounds.

\subsection{Sample C}

Sample $\mathrm{C}$ is atypical in many respects. It differs from the other groups not only in the use of glaze, but also the whole character of the matrix (less temper) and manufacturing technologies (throwing, thin walls). On the other hand, the glaze was found to be uneven, some subtle defects were found on the vessel surface, and high water absorption was identified $(16.02 \%)$. There were no coarse elements in the matrix. In the medium component there were lightly to moderately smoothed grains of quartz sand (Table 4). The brown-coloured soft component showed the presence of iron compounds. More surprising than the firing temperature, which was found to be above $720{ }^{\circ} \mathrm{C}$ in an oxidizing atmosphere is the length of the firing process. The ability to maintain a constant temperature for a longer interval of time is considered an advanced manufacturing process. The overall differences in the sample could indicate foreign production or provenance, or the use of advanced manufacturing technologies of the post-mediaeval period.

\subsection{Sample D}

Sample D represents production which stems from the mediaeval tradition. Its popularity did not end even with the emergence of new technologies, especially the glaze. It seems that the potters were able to achieve relatively high standards of manufacturing not only during the forming process, but also during firing. Compared with the glazed sample the high firing temperature is surprising (up to $800^{\circ} \mathrm{C}$, oxidizing atmosphere) and also corresponds with the very low water absorption (10.47\%). The coarse component is least frequent (Table 4) while the most frequent fine component is quite homogeneous and suggests careful preparation of the matrix. The dark brown colour of the fine component indicates the

\footnotetext{
${ }^{12}$ It is interesting that the high firing temperatures declared for red pottery by, for instance, M. Richter, were not confirmed (Richter 1982, 104).
} 
presence of iron compounds. Contrary to expectations, this sample is the highest quality product of all the samples analysed as regards functionality due to lower absorption.

\subsection{Sample E}

Sample E is the opposite of the previous group. Despite the relatively "modern" look, its quality is comparable to pottery from the time of the town's foundation. A low firing temperature $\left(660{ }^{\circ} \mathrm{C}\right.$, reduction atmosphere) and high water absorption (16.61\%) were identified. The presence of coarse component was quite low (Table 4) and the predominance of very lightly smoothed grains of quartz links this with the previous group. Use of the smoking technique was confirmed by the presence of carbon substance on the surface of body which entered the open pores from wood burned in firing. It is said that with this technique the vessels became more watertight. In the case of our relatively porous sample, this appears not to be the main criterion of quality. The visually smooth appearance of the surface was probably achieved using finely washed clays.

\section{Conclusions}

If we compare the results of analyses provided at Turnov's pottery, it's evident that extreme values (as mentioned above) of firing temperatures were not confirmed. The laboratory work gave the generally accepted values (between 600 and $900{ }^{\circ} \mathrm{C}$ ), with none of the samples exceeding them considerably. When comparing the resulting data for individual samples, we noted that they are quite disparate. This finding confirms both the diversity of their dating and our uncertainty regarding the possible unified line of production.

The composition of the matrix indicates that different methods were used to prepare the ceramics. Samples A and E seems to have been purposefully added with river sand into the matrix, while the small amount of coarse-grained component in sample D indicates that the clay was carefully purged from most of the bigger grains. The structure of sample E indicates the use of finely washed clay, as with sample $\mathrm{C}$ which lacks the larger non-plastic compounds. In all five samples, clay with considerable plasticity was used, often enriched with iron compound. The compound of clay was without marked differences in all of them (see Table 3). But the nature of the temper and the methods used to process the ceramic mass give the impression that each of the represented groups is unique.

The misleading influence of macroscopic observation was confirmed in connection with the contents of the non-plastic components, as already mentioned in some earlier works (Kociszewski and Kruppe 1964). The visual impression of quality contrasts unexpectedly with the laboratory analysis, especially in samples D and E. The assumption that the quality of ceramic products improves over time was also not confirmed. For example it was found out that the firing temperature of samples A and D are quite low, whereas both samples are at the opposite ends of the time span. In our case, however, this discovery can only be used for sketching in because of our incomplete knowledge of Turnov pottery production and due to the scarcity of samples analysed.

From what we know we cannot clearly assess which pottery assemblage may have been manufactured in Turnov and which arrived from elsewhere from likely trade. With a certain degree of caution we assume that group A was produced locally. It is the only known pottery from the earliest period of the town and shows a fairly low standard of production.

The region of the Jizera River could have been well supplied by local red-painted ware makers, though wellknown production sites of this pottery were located several dozen kilometres from Turnov (Levín, Česká Lípa; Zápotocký 1978, 230-231). However, as demonstrated by the kiln at Pelešany, by the $14^{\text {th }}$ century ceramics decorated with red painting were also produced in the immediate vicinity of the town.

Even in group D we expect local production due to its occurrence throughout north-eastern Bohemia. The popularity of this so-called "red ware" can be explained by its easy availability, being undoubtedly cheaper than the newly emerging glazed pottery, and qualitative properties (e.g. low water absorption). No production equipment for groups $\mathrm{C}$ and $\mathrm{E}$ has been found in the vicinity of Turnov.

At the same time the composition of the matrix includes no such specific additives that imply foreign sources of raw materials. Both glazed and smoked potteries were common goods in the post-mediaeval period and it is assumed that they were easily available. The expansion of both groups corresponds to the flourishing of the craft in Turnov in early modern times, as is documented by written sources. Under those circumstances there is no particular reason why local potters could not have manufactured them.

It is apparent that although the use of scientific analysis in this case has brought answers to some commonly asked questions, such as the firing temperature or the structure of ceramics mass, it has also given rise to new and more precisely formulated questions. To resolve them, more samples are required for analysis, and such samples which came from more specific and intimately determined groups. This requires the creation of new sub-groups of pottery besides the existing general ones. In future, continuing interdisciplinary collaboration could help to structure more specific questions and consequently provide us with a clearer picture of pottery manufacture in Turnov and the wider region.

This necessitates a critical evaluation of the results and application of these analytical methods in order to avoid recurrent errors. In some cases there is a problem in the Czech Republic concerning how archaeologists cooperate with such laboratories and how they should ask their questions to avoid mutual misunderstanding. Finally, the primary purpose of an evaluation should not be to justify the results of one of the laboratories, but rather a broader discussion of the approaches and findings of all the individual laboratories. Despite some 
attempts at synthesis, the application of scientific analyses still seems to lack a coherent concept. Under these circumstances it is quite difficult to reach a consensus in this topic.

\section{References}

BRATHER, S. 2002: Raně a vrcholně středověká keramika západních Slovanů. In: Střed Evropy okolo roku 1000. 46-48, Praha.

BYSTROEM, A. M. 1955: Beitrag zur Untersuchung der Brenntemperatur von Tonwaren. In: Selling, D. (Ed.): Wikingerzeitliche und Fruehmittelalterliche Keramik in Schweden. 250-251, Stockholm.

DOHNAL, M., KOUCKÝ, K. 2000: Analýza části novověkých nálezů $\mathrm{z}$ archeologického výzkumu městské parcely v Sedlčanech (okr. Příbram), Archeologické výzkumy v severozápadních Čechách 4, 359-382.

DVORSKÁ, J., POLÁČEK, L. 1995: Mineralogisch - petrographische Charakteristik der Mikulčice Keramik. In: Poláček, L. (Ed.): Slawische Keramik in Mitteleuropa vom 8. bis 11. Jahrhundert - Terminologie und Beschreibung. Internationale Tagungen in Mikulčice II. 196-203, Brno.

GREGEROVÁ, M., ČOPJAKOVÁ, R., BERÁNKOVÁ, V., BIBR, P., GOŠ V., HANULÁKOVÁ, D., HLOŽEK, M., HOLUBOVÁ-ZÁVODNÁ, B., KRISTOVÁ, L., KULJOVSKÁ, Z., MACHÁČEK, J., MAZUCH, M., PROCHÁZKA, R., ŠKODA, R., VŠIANSKÝ, D. 2010: Petroarcheologie keramiky v historické minulosti Moravy a Slezska. Brno.

GREGEROVÁ, M., KRISTOVÁ, L. 1995: Probleme der Interpretation der differenztermischen Analysen der Graphittonkeramik. In: Poláček, L. (Ed.): Slawische Keramik in Mitteleuropa vom 8. bis zum 11. Jahrhunderts - Terminologie und Beschreibung. - II. Internationale Tagungen in Mikulčice. 213-222, Brno.

GRIM, R. E. 1968: Clay mineralogy. McGraw-Hill, New York.

HANYKÝŘ, V., MARYŠKA, M., PROFANTOVÁ, N. 2002: Mikroanalýzy keramických zlomkủ z Doubravčic, okr. Kolín, Archeologické výzkumy v severozápadních Čechách 6, 493-497.

HANYKÝR̆, V., MARYŠKA, M., PROFANTOVÁ, N. 2005: Exkurs 2: Výsledky prírodovědných analýz keramických střepů; In: Nové objekty kultury s keramikou pražského typu z Roztok u Prahy, Památky archeologické XCVI, 127-164.

HULTHEN, B., BRORSSON, T. 2007: Viking Age and early Mediaeval Pottery in western Russia, Archaeologisches Korrespondenzblatt 37, 597-610.

KLÁPŠTĚ, J. 2005: Proměna českých zemí ve středověku. Praha.
KOCISZEWSKI, L., KRUPPE, J. 1964: A method of physico-chemical investigation prompting the study of technology in the history of pottery production, Archeologia Polona 6, 158-184.

MACHÁČEK, J. 2001: Studie k velkomoravské keramice. Metody, analýzy a syntézy, modely.

MATOUŠEK, V., SCHEUFLER, V. 1983: Raně novověké berounské zboží ve světle archeologických výzkumů v Berouně, Archeologica Historica 13, 189-196.

NEKUDA, V., REICHERTOVÁ, K. 1968: Středověká keramika v Čechách a na Moravě. Brno.

PROSTŘEDNÍK, J. 1997: Archeologické výzkumy Okresního muzea Českého ráje v Turnově v roce 1996, Z Českého ráje a Podkrkonoši 10, 139-162.

PROSTŘEDNÍK, J. 2000: Pravěké a středověké osídlení Turnova ve světle archeologických nálezů, Z Českého ráje a Podkrkonoši 13, 7-49.

RICE, P. M. 2005: Pottery analysis. London.

RICHTER, M. 1982: Hradištko u Davle. Městečko ostrovského kláštera. Praha.

RZEŹNIK, P., STOKSIK, H. 2004: Silesian graphitonkeramik of the $12^{\text {th }}-13^{\text {th }}$ centuries in the light of specialist analyse of vessels from Racibórz, Archeologické rozhledy 56, 321-342.

SKRUŽNÝ, L. 1974: Z historie hrnčiřských cechů na území Čech, Zpravodaj středočeské vlastivédy a kronikářstvi VI, 178-205.

STOKSIK, H. 2007: Technologia warsztatu ceramicznego średniowiecznego Ślaska $w$ świetle badań specjalistycznych $i$ eksperymentalnych. Wrocław.

ŠŤASTNÁ, M. 1998: Mineralogické studium středověké keramiky. MS. Master diploma thesis. Deposited:Library of the Faculty of Sciences of the Charles University in Prague.

TAYLOR, R. E. 1960: Impregnation of rocks for sectioning, Geological Magazine 97, 261.

WALDHAUSER, J. 1980: Sídla drobné šlechty v severním Pojizeří a na Liberecku, Zprávy a studie Krajského muzea v Teplicích 14, 49-65.

WINTER, Z. 1913: Český primysl a obchod v XVI. věku. Praha.

ZAVŘEL, J., ŽEGKLITZ, J. 1990: Geochemical and petrographical studies of the post-mediaeval pottery of the Prague and Beroun regions. In: Studies in Postmediaeval Archaeology 1.95-126, Praha.

ZÁPOTOCKÝ, M. 1978: Středověká keramika severočeského Polabí, Památky archeologické 69/1, 171-238.

ZUSSMAN, J. (Ed.) 1977: Physical methods in determinative mineralogy. London. 